\title{
Identification of Synergistic Interaction Between Cannabis-Derived Compounds for Cytotoxic Activity in Colorectal Cancer Cell Lines and Colon Polyps That Induces Apoptosis-Related Cell Death and Distinct Gene Expression
}

Rameshprabu Nallathambi, ${ }^{1, \dagger}$ Moran Mazuz, ${ }^{1, \dagger}$ Dvory Namdar, ${ }^{1}$ Michal Shik, ${ }^{1,2}$ Diana Namintzer, ${ }^{1,2}$ Ajjampura C. Vinayaka, Aurel Ion, ${ }^{1}$ Adi Faigenboim, ${ }^{1}$ Ahmad Nasser, ${ }^{3}$ Ido Laish, ${ }^{4}$ Fred M. Konikoff, ${ }^{4,5}$ and Hinanit Koltai ${ }^{1, *}$

\begin{abstract}
Introduction: Colorectal cancer remains the third most common cancer diagnosis and fourth leading cause of cancer-related mortality worldwide. Purified cannabinoids have been reported to prevent proliferation, metastasis, and induce apoptosis in a variety of cancer cell types. However, the active compounds from Cannabis sativa flowers and their interactions remain elusive.

Research Aim: This study was aimed to specify the cytotoxic effect of C. sativa-derived extracts on colon cancer cells and adenomatous polyps by identification of active compound(s) and characterization of their interaction. Materials and Methods: Ethanol extracts of C. sativa were analyzed by high-performance liquid chromatography and gas chromatograph/mass spectrometry and their cytotoxic activity was determined using alamarBlue-based assay (Resazurin) and tetrazolium dye-based assay (XTT) on cancer and normal colon cell lines and on dysplastic adenomatous polyp cells. Annexin V Assay and fluorescence-activated cell sorting (FACS) were used to determine apoptosis and cell cycle, and RNA sequencing was used to determine gene expression.

Results: The unheated cannabis extracts (C2F), fraction 7 (F7), and fraction 3 (F3) had cytotoxic activity on colon cancer cells, but reduced activity on normal colon cell lines. Moreover, synergistic interaction was found between F7 and F3 and the latter contains mainly cannabigerolic acid. The F7 and F7 + F3 cytotoxic activity involved cell apoptosis and cell cycle arrest in S or G0/G1 phases, respectively. RNA profiling identified 2283 differentially expressed genes in F7+F3 treatment, among them genes related to the Wnt signaling pathway and apoptosisrelated genes. Moreover, F7, F3, and F7+F3 treatments induced cell death of polyp cells.

Conclusions: C. sativa compounds interact synergistically for cytotoxic activity against colon cancer cells and induce cell cycle arrest, apoptotic cell death, and distinct gene expression. F3, F7, and F7+F3 are also active on adenomatous polyps, suggesting possible future therapeutic value.
\end{abstract}

Keywords: Cannabis; colorectal cancer; apoptosis; synergism; cell cycle arrest; cytotoxicity

\footnotetext{
${ }^{1}$ Agricultural Research Organization, Volcani Center, Bet Dagan, Israel.

${ }^{2}$ The Mina and Everard Goodman Faculty of Life Sciences, Bar-llan University, Ramat Gan, Israel.

${ }^{3}$ The Interinstitutional Analytical Instrumentation Unit (IU), ARO, Volcani Center, Bet Dagan, Israel.

${ }^{4}$ Department of Gastroenterology and Hepatology, Meir Medical Center, Kfar Saba, Israel.

${ }^{5}$ Sackler Faculty of Medicine, Tel Aviv University, Tel Aviv, Israel.

These authors contributed equally to this article.
}

*Address correspondence to: Hinanit Koltai, PhD, Agricultural Research Organization, Volcani Center, Bet Dagan 7528809, Israel, E-mail: hkoltai@agri.gov.il

(c) Rameshprabu Nallathambi et al. 2018; Published by Mary Ann Liebert, Inc. This Open Access article is distributed under the terms of the Creative Commons License (http://creativecommons.org/licenses/by/4.0), which permits unrestricted use, distribution, and reproduction in any medium, provided the original work is properly cited. 


\section{Introduction}

Although there has been some reduction in mortality caused by colorectal cancer (CRC) due to advances in screening and preventive colonoscopies, it remains the third most common cancer diagnosis and fourth leading cause of cancer-related mortality worldwide. ${ }^{1}$ CRC is a heterogeneous disease that differs in clinical presentation, molecular characteristics, and prognosis. ${ }^{2}$ A series of histopathological and molecular changes lead the normal colonic epithelial cells to form aberrant crypt foci (ACF) and polyps that can further develop into CRC. ${ }^{3}$ As well, adenomatous polyps are recognized precursors of CRC. ${ }^{4,5}$ In addition to polypectomies, chemoprevention with natural or synthetic agents is another cornerstone of primary prophylactic intervention. Because the natural history of CRC is protracted, clinical trials have concentrated on preventing adenomas, which represent a form of intraepithelial neoplasia and are the precursors to carcinoma.

Cannabis sativa contains more than 500 constituents, among them more than a hundred terpenophenolic compounds termed phytocannabinoids. ${ }^{6}$ An increasing number of studies have shown that phytocannabinoids can prevent proliferation, metastasis, and angiogenesis, and induce apoptosis in a variety of cancer cell types, including breast, lung, prostate, skin, intestine, glioma, and others. ${ }^{7}$ This is due to their ability to regulate signaling pathways critical for cell growth and survival. ${ }^{7}$ Tetrahydrocannabinol (THC) treatment induced apoptosis in a CB1-dependent way in CRC cells and inhibited various survival signaling cascades while activating the proapoptotic BCL-2 family member $\mathrm{BAD}{ }^{8}$ Cannabidiol (CBD) reduced cell proliferation in colorectal carcinoma cell lines. In an animal model, it reduced ACF (preneoplastic lesions), polyps, and tumor formation and counteracted colon cancer-induced changes in gene expression. ${ }^{9}$ A CBDrich cannabis extract also was shown to inhibit CRC cell proliferation and attenuate colon carcinogenesis. ${ }^{10}$ This activity involved both $\mathrm{CB} 1$ and $\mathrm{CB} 2$ receptor activation. ${ }^{10}$ Cannabigerol (CBG) promoted apoptosis, stimulated reactive oxygen species (ROS) production, and reduced cell growth in CRC cells. In vivo, CBG inhibited the growth of chemically induced colon carcinogenesis and xenograft tumors. ${ }^{11}$

Despite the accumulating knowledge on THC, CBD, and $\mathrm{CBG}$, and receptor agonists or antagonists, only little is known on the other compounds in cannabis extracts that may have anticancer properties. Moreover, since advantages to the unrefined content of the inflo- rescence versus an isolated compound have been reported, ${ }^{12,13}$ beneficial interactions between active compounds should be examined.

In this study, we identified the C. sativa extract fractions and compounds that have cytotoxic activity on CRC cells and adenomatous polyps and evidenced their synergistic interaction. The interacting compounds induced cell cycle arrest, apoptotic cell death, and distinct gene expression.

\section{Materials and Methods}

Extraction of Cannabis inflorescence

Fresh inflorescences of $C$. sativa CS12 var were harvested from plants. They were either taken immediately for extraction and frozen at $-80^{\circ} \mathrm{C}$, or heated for $2.5 \mathrm{~h}$ at $150^{\circ} \mathrm{C}$ before extraction. Fresh and heated Cannabis inflorescences $(2 \mathrm{~g})$ were pulverized with liquid nitrogen. Absolute ethanol was added to each tube containing the powder at sample-to-absolute ethanol ratio of $1: 4(\mathrm{w} / \mathrm{v})$. The tubes were mixed thoroughly on a shaker for $30 \mathrm{~min}$ and then the extract was filtered through a filter paper. The filtrate was transferred to new tubes. The solvent was evaporated with a vacuum evaporator. The dried extract was resuspended in $1 \mathrm{~mL}$ of absolute methanol and filtered through a $0.45-\mu \mathrm{m}$ syringe filter (Merck, Darmstadt, Germany). For the treatments, the resuspended extract was diluted accordingly for cell cultures and biopsies in all experiments.

\section{Sample preparation}

For high-performance liquid chromatography (HPLC), the dry extract was resuspended in $1 \mathrm{~mL}$ of methanol and filtered through a $0.45-\mu \mathrm{m}$ syringe filter. The filtered extract was diluted 10 times with methanol and then separated by HPLC.

\section{HPLC separation and quantification}

Sample separation was carried out in an UltiMate 3000 HPLC system coupled with WPS-3000(T) Autosampler, HPG-3400 pump, and DAD-300 detector. The separation was performed on a Purospher RP-18 endcapped column $(250 \mathrm{~mm} \times 4.6 \mathrm{~mm}$ I.D.; Merck KGaA, Darmstadt, Germany) with a guard column $(4 \mathrm{~mm} \times 4$ $\mathrm{mm}$ I.D.). Solvent gradients were formed by isocratic proportion with $15 \%$ solvent $\mathrm{A}(0.1 \%$ acetic acid in water) and $85 \%$ solvent $\mathrm{B}$ (methanol) at a flow rate of $1.5 \mathrm{~mL} / \mathrm{min}$ for $35 \mathrm{~min}$. The compound peaks were detected at 220 , and $280 \mathrm{~nm}$. The $220-\mathrm{nm}$ peaks were taken for further processing. The extracts were 
fractionated into nine fractions according to the obtained chromatogram. Tetrahydrocannabinolic acid (THCA; LGC standards) and cannabigerolic acid (CBGA; LGC standards) were used as external calibration standards for quantification of cannabinoids, at suitable concentrations ranging 5-20 $\mu \mathrm{g}$.

\section{Gas chromatography coupled with mass} spectrometer analysis

Gas chromatography (GC)/mass spectrometry (MS) analyses were carried out using a HP7890 GC coupled to a HP6973 mass spectrometer with electron multiplier potential $2 \mathrm{kV}$, filament current $0.35 \mathrm{~mA}$, electron energy $70 \mathrm{eV}$, and the spectra were recorded over the range $\mathrm{m} / \mathrm{z}$ 40 to 400. An Agilent 7683 autosampler was used for sample introduction. Helium was used as a carrier gas at a constant flow of $1.1 \mathrm{~mL} \mathrm{~s}^{-1}$. An isothermal hold at $50^{\circ} \mathrm{C}$ was kept for $2 \mathrm{~min}$, followed by a heating gradient of $6^{\circ} \mathrm{C} \mathrm{min}{ }^{-1}$ to $300^{\circ} \mathrm{C}$, with the final temperature held for $4 \mathrm{~min}$. A $30 \mathrm{~m}, 0.25 \mathrm{~mm}$ I.D. $5 \%$ crosslinked phenylmethylsiloxane capillary column (HP-5MS) with a $0.25 \mu \mathrm{m}$ film thickness was used for separation and the injection port temperature was $220^{\circ} \mathrm{C}$. The MS interface temperature was $280^{\circ} \mathrm{C}$. Peak assignments were performed with a spectral library (NIST 14.0) and compared with published and MS data obtained from the injection of standards (LGC standards). For identification and partial quantification, $5 \mu \mathrm{g}$ of the most common cannabinoid standards, CBGA, cannabidiolic acid (CBDA), THCA, cannabichromene (CBC), and cannabinol (CBN), were dissolved in methanol and were injected to the GC/MS. Before GC/MS analysis, $200 \mu \mathrm{L}$ of N,O-bis(trimethylsilyl)trifluoroacetamide (BSTFA; Sigma-Aldrich, St. Louis) containing $1 \%$ of trimethylchlorosilane (TMCS) was added to each completely dried extract and heated to $70^{\circ} \mathrm{C}$ for $20 \mathrm{~min}$. One microliter of each sample was injected to the GC/MS using a 1:10 split ratio injection mode.

Cell cultures

HCT 116 (ATCC CCL-247), HT-29 (ATCC HTB-38), Caco-2 (ATCC HTB-37), and CCD-18Co (ATCC CRL-1459) colon cells were grown at $37^{\circ} \mathrm{C}$ in a humidified 5\% $\mathrm{CO}_{2}-95 \%$ air atmosphere. Cells were maintained in McCoy's 5a Modified Medium (for HT-29 and HCT 116 cell lines), Dulbecco's Modified Eagle's Medium (DMEM; for Caco-2 cells) and Eagle's Minimum Essential Medium (EMEM; for CCD-18Co cell line; all cell lines were kindly provided by Prof. Margel, Bar Ilan University, Israel).

\section{Determination of extracts and compounds}

cytotoxic activity in cell lines

Resazurin (alamarBlue, R\&D Systems, Minneapolis) was used to check the cytotoxic effect of extracts. For this, $10 \%$ Resazurin was added to each well of the treatments and incubated for $4 \mathrm{~h}$ at $37^{\circ} \mathrm{C}$ in a humidified $5 \%$ $\mathrm{CO}_{2}-95 \%$ air atmosphere.

The relative fluorescence at the excitation/emission of $544 / 590 \mathrm{~nm}$ was measured. The percentage of live cells was calculated relative to the nontreated control after reducing the autofluorescence of alamarBlue without cells. Dose-effect curves of $C$. sativa ethanol extracts of fresh inflorescences $(\mathrm{C} 2 \mathrm{~F})$, heated inflorescences (C2B) for HCT 116 colon cancer cells, and CCD-18Co colon healthy cells were determined. HCT 116 and CCD-18Co cells were seeded $(10,000$ per well) in triplicate in $100 \mu \mathrm{L}$ growing media and incubated for $24 \mathrm{~h}$ at $37^{\circ} \mathrm{C}$ in a humidified $5 \% \mathrm{CO}_{2}-95 \%$ air atmosphere. Cells were treated with $\mathrm{C} 2 \mathrm{~F}, \mathrm{C} 2 \mathrm{~B}$ at different dilutions $(35-1600 \mu \mathrm{g} / \mathrm{mL})$ along with $50 \mathrm{ng} / \mathrm{mL}$ tumor necrosis factor (TNF- $\alpha$ ) for $16 \mathrm{~h}$. Afterward, the viability of the cells was determined with alamarBlue. GraphPad Prism was employed to produce a dose-response curve and IC50 doses of $\mathrm{C} 2 \mathrm{~F}$ and $\mathrm{C} 2 \mathrm{~B}$.

\section{$\mathrm{XTT}$ viability assay}

Cells were seeded into a 96-well plates at a concentration of 10,000 cells per well in triplicate in normal growing media. The following day, the media were replaced with normal growing media containing plant extracts/fractions, standards (CBGA and THCA), or media only for control (as mentioned in each experiment). Cells were incubated for $48 \mathrm{~h}$, after which XTT (2,3,-bis (2-methoxy4-nitro-5-sulfophenyl)-5-[(phenylamino)-carbonyl]-2Htetrazolium inner salt) reduction was used to quantify viability according to the manufacturer's instruction (BI, Kibbutz Beit-Haemek, Israel). Cells were incubated with XTT reagent for $2 \mathrm{~h}$ at $37^{\circ} \mathrm{C}$ in a humidified $5 \% \quad \mathrm{CO}_{2}-95 \%$ air atmosphere. Absorbance was recorded by a photometer, SPEKTRA Fluor Plus (Tecan, Salzburg, Austria), at $490 \mathrm{~nm}$ with $650 \mathrm{~nm}$ of reference wavelength. Cell survival was estimated from the equation: $\%$ cell survival $=100 \times($ At $-A c)$ (treatment)/(At - Ac)(control); At and Ac are the absorbencies $(490 \mathrm{~nm})$ of the XTT colorimetric reaction (BI) in treated and control cultures, respectively, minus nonspecific absorption that was measured at $650 \mathrm{~nm}$. Absorbance of medium alone was also deducted from specific readings. 


\section{Analysis of combined effects}

To examine synergy between F3 and F7 cytotoxic activity, XTT assay was used on HCT 116 cells as described above. Different concentrations of F3 $(3.7-80.0 \mu \mathrm{g} / \mathrm{mL})$, with and without the IC50 dose of F7 $(20 \mu \mathrm{g} / \mathrm{mL})$, or different concentrations of F7 $(7.9-63.0 \mu \mathrm{g} / \mathrm{mL})$ with and without the IC50 dose of F3 $(36 \mu \mathrm{g} / \mathrm{mL})$ were used to treat the cells for $48 \mathrm{~h}$. Next, the cells were incubated with XTT reagent for $2 \mathrm{~h}$ as described above. For examination of synergy between standards, different concentrations of THCA $(4.0-50.0 \mu \mathrm{g} / \mathrm{mL})$ with and without CBGA $(28 \mu \mathrm{g} / \mathrm{mL})$, or different concentrations of CBGA (6.7$53.3 \mu \mathrm{g} / \mathrm{mL})$ with and without THCA $(13.14 \mu \mathrm{g} / \mathrm{mL})$ were used. The range of concentrations for examination of synergy on cell viability for the THCA or CBGA standards was determined based on quantification of THCA in F7 or CBGA in F3 using HPLC (as described above). Drug synergy was determined by Bliss independence drug interaction model, ${ }^{14}$ which is defined by the following equation:

$$
E_{x y}=E_{x}+E_{y}-\left(E_{x} E_{y}\right),
$$

where $\left(E_{x y}\right)$ is the additive effect of the drugs $x$ and $y$ as predicted by their individual effects $\left(\mathrm{E}_{\mathrm{x}}\right.$ and $\left.\mathrm{E}_{\mathrm{y}}\right)$. For the calculation purposes in this article, the anticancer effect of the drug was defined as complementary to the obtained results $\left(1-\mathrm{E}_{\mathrm{xy}}\right)$. In case the observed value of $E_{x y}$ is greater than the calculated $E_{x y}$ value, the combination treatment is considered antagonistic. If the observed value is less than the calculated one, then the combination treatment is considered synergistic. If both values are equal, the combination treatment is considered additive (independent).

Drug synergy was also determined by combination index (CI) methods, derived from the median-effect principle. ${ }^{15}$ Data obtained from the growth inhibitory experiments were used to perform these analyses. Combination data points that fall on the line represent an additive drugdrug interaction, whereas data points that fall below or above the line represent synergism or antagonism, respectively. The CI method is a mathematical and quantitative representation of a two-drug pharmacologic interaction. Using data from the growth inhibitory experiments, CI value was calculated using CompuSyn software (ComboSyn, Inc.) as described in the equation below

$$
\mathrm{CI}=\frac{\mathrm{C}_{\mathrm{A}, \mathrm{x}}}{\mathrm{IC}_{\mathrm{x}, \mathrm{A}}}+\frac{\mathrm{C}_{\mathrm{B}, \mathrm{x}}}{\mathrm{IC}_{\mathrm{x}, \mathrm{B}}}
$$

$\mathrm{C}_{\mathrm{A}, \mathrm{x}}$ and $\mathrm{C}_{\mathrm{B}, \mathrm{x}}$ are the concentrations of drug $\mathrm{A}$ and drug $B$ used in combination to achieve percentage of drug effect. $\mathrm{IC}_{\mathrm{x}, \mathrm{A}}$ and $\mathrm{IC}_{\mathrm{x}, \mathrm{B}}$ are the concentrations for single agents to achieve the same effect. CI values are generated over a range of fraction affected levels from 0.25 to 0.90 (25\%-90\% growth inhibition). A CI of 1 indicates an additive effect between two drugs, whereas a $\mathrm{CI}<1$ or CI $>1$ indicates synergism or antagonism, respectively.

Annexin $V$ assay

Apoptosis was assessed using the MEBCYTO Apoptosis Kit with Annexin V-FITC and Propidium Iodide (PI) (MBL, Enco, 4700). Staining was done according to the manufacturer's instructions. In brief, cells were seeded in 6-well plate culture dishes, at density of $1 \times 10^{6}$ cells per well in McCoy's 5a Modified Medium. The following day, the medium was replaced with medium containing IC-50 dose of F7 $(20 \mu \mathrm{g} / \mathrm{mL})$, F3 $(35 \mu \mathrm{g} / \mathrm{mL})$ and combination of F7 and F3 along with TNF- $\alpha(50 \mathrm{ng} / \mathrm{mL})$ and incubated for 24 and $48 \mathrm{~h}$ at $37^{\circ} \mathrm{C}$ in a humidified $5 \%$ $\mathrm{CO}_{2}-95 \%$ air atmosphere. After incubation, cells were harvested and collected separately. Then tubes were centrifuged for $10 \mathrm{~min}$ at $900 \mathrm{~g}$ relative centrifugal force (RCF) and cell pellets were resuspended and washed twice with $1 \mathrm{~mL}$ of phosphate-buffered saline (PBS). The cells in each sample were counted and if necessary, the number of cells was adjusted to a concentration of $2 \times 10^{5}$ cells in $85 \mu \mathrm{L}$ of Annexin binding buffer. Cells were stained using $10 \mu \mathrm{L}$ of Annexin V-FITC solution and $5 \mu \mathrm{L}$ of PI working solution followed by incubation in darkness at room temperature for $15 \mathrm{~min}$. Then $400 \mu \mathrm{L}$ of Annexin $\mathrm{V}$ binding buffer was added to each tube and flow cytometry was performed using GALLIOS flow cytometer (fluorescence-activated cell sorting [FACS]). Cells were considered to be apoptotic if they were Annexin V+/PI- (early apoptotic) and Annexin $\mathrm{V}+/ \mathrm{PI}+$ (late apoptotic). Live cells were Annexin V-/PI- and Annexin V-/PI+ are the necrosis.

\section{Cell cycle analysis}

Cells were seeded in 6-well plate culture dishes at a density of $1 \times 10^{6}$ cells per well. After $24 \mathrm{~h}$ of seeding, the cell culture media were replaced with starvation media and incubated for $24 \mathrm{~h}$ at $37^{\circ} \mathrm{C}$ in a humidified $5 \% \mathrm{CO}_{2}-95 \%$ air atmosphere. After $24 \mathrm{~h}$ of incubation, the cells were treated with F7 $(20 \mu \mathrm{g} / \mathrm{mL})$, F3 $(36 \mu \mathrm{g} /$ $\mathrm{mL}), \mathrm{F} 7$ in combination with F3 and solvent control along with TNF- $\alpha(50 \mathrm{ng} / \mathrm{mL})$ for another $24 \mathrm{~h}$. Then the cells from each well were harvested and collected separately and centrifuged for $10 \mathrm{~min}$ at $900 \mathrm{~g}$. The cell pellets were washed once with $1 \mathrm{~mL}$ of PBS and fixed with $70 \%$ cold ethanol at $4^{\circ} \mathrm{C}$ for $1 \mathrm{~h}$. The fixed cells were then pelleted out and washed twice with 
$1 \mathrm{~mL}$ of PBS. The cell pellet was then stained by resuspending in $250 \mu \mathrm{L}$ of PI solution $(50 \mu \mathrm{g} / \mathrm{mL})$ containing RNase A $(100 \mu \mathrm{g} / \mathrm{mL})$ for $15 \mathrm{~min}$ in darkness. Then $400 \mu \mathrm{L}$ of PBS was added to each tube and the cells were analyzed using GALLIOS flow cytometer.

\section{Culture of biopsies}

Biopsies from polyps and healthy colonic tissue from the same patient were obtained from seven patients scheduled for colonoscopies deemed necessary by their physicians. The study was approved by our Institutional Ethics Committee (Helsinki approval no. 0121-16), and all patients gave their written informed consent before the colonoscopy. Biopsies taken during each colonoscopy were placed in tissue culture media and immediately transported to the laboratory. Upon receiving the biopsies, the PBS was replaced with Hank's Balanced Salt Solution and the samples were centrifuged at $8000 \mathrm{rpm}(5,939 \mathrm{~g})$ for $1 \mathrm{~min}$. The supernatant was then removed and the tissues were washed four times with Hank's Balanced Salt Solution. After each wash, samples were centrifuged as described above. The tissues were placed in a small Petri dish and cut into 4-5 pieces with a clean scalpel. The pieces were then placed on Millicell hydrophilic PTFE tissue-culture inserts ( $30 \mathrm{~mm}, 0.4 \mu \mathrm{m}$; Millipore). The inserts were placed in 6-well plastic tissue culture dishes (Costar 3506) along with $1.5 \mathrm{~mL}$ of tissue culture medium (DMEM supplemented with $10 \% \mathrm{v} / \mathrm{v}$ heatinactivated fetal calf serum, $100 \mathrm{U} / \mathrm{mL}$ penicillin, $100 \mu \mathrm{g} /$ $\mathrm{mL}$ streptomycin, $50 \mu \mathrm{g} / \mathrm{mL}$ leupeptin, $1 \mathrm{mM}$ PMSF, and $50 \mu \mathrm{g} / \mathrm{mL}$ soybean trypsin inhibitor). This treatment was followed by treating the tissues with extracts, or leaving them untreated (control). The treatment medium was replaced with a medium containing C2F $(1.25 \mathrm{mg} / \mathrm{mL})$, F7 (at different concentrations: 100, 125, 250, or $400 \mu \mathrm{g} /$ $\mathrm{mL}$ ), F3 $(75,107$, or $176 \mu \mathrm{g} / \mathrm{mL}$ ), or F3 + F7 (at the desired concentrations) and incubated overnight at $37^{\circ} \mathrm{C}$ in a humidified 5\% $\mathrm{CO}_{2}-95 \%$ air atmosphere.

\section{Cell separation and Resazurin for biopsies}

After $16 \mathrm{~h}$, the treated and untreated tissues from the above section were taken into a tube and washed twice with PBS. Then the tissues were transferred into a Petri dish and chopped into very fine pieces using a surgical scalpel. The finely chopped pieces were transferred into tubes and $500 \mu \mathrm{L}$ of R10 medium (RPMI 1640 supplemented with $10 \%$ FBS, $10 \mathrm{mM}$ HEPES, $100 \mathrm{U} / \mathrm{mL}$ penicillin, $100 \mu \mathrm{g} / \mathrm{mL}$ streptomycin, and $50 \mu \mathrm{g} / \mathrm{mL}$ gentamicin) was added along with $20 \mathrm{IU} / \mathrm{mL}$ of DNase, 0.13 units $/ \mathrm{mL}$ of dispase, and $1 \mathrm{mg} / \mathrm{mL}$ of collagenase
1A. Then the tissues were vortexed and incubated at $37^{\circ} \mathrm{C}$ for $1 \mathrm{~h}$ by vortexing every 15 minutes in between. Subsequently, the cell suspensions were pelleted at 950 $g$ for $10 \mathrm{~min}$ and washed twice with PBS buffer. The cell suspension pellets were resuspended with $500 \mu \mathrm{L}$ R10 medium and incubated at $37^{\circ} \mathrm{C}$ in a humidified $5 \% \mathrm{CO}_{2}-95 \%$ air atmosphere with $10 \%$ Resazurin for $4 \mathrm{~h}$. The supernatant ( $100 \mu \mathrm{L}$ from each well) was transferred to a 96-well plate and the relative fluorescence at the excitation/emission of $544 / 590 \mathrm{~nm}$ was measured. The percentage of live cells was calculated relative to the nontreated control after reducing the autofluorescence of alamarBlue without cells.

\section{RNA sequencing and transcriptome analysis}

For RNA preparation, cells were seeded into a 6-well plate at a concentration of $1,500,000 \mathrm{cell} / \mathrm{mL}$ per well. After $24 \mathrm{~h}$ of incubation at $37^{\circ} \mathrm{C}$ in a humidified $5 \%$ $\mathrm{CO}_{2}-95 \%$ air atmosphere, cells were treated with $\mathrm{F} 3$ $(36 \mu \mathrm{g} / \mathrm{mL}), \mathrm{F} 7(20 \mu \mathrm{g} / \mathrm{mL})$ and combination of F3 with F7 at these concentrations along with TNF- $\alpha$ $(50 \mathrm{ng} / \mathrm{mL})$ for $6 \mathrm{~h}$. The cells were next harvested and total RNA was extracted using a TRI reagent (SigmaAldrich) according to the manufacturer's protocol. The RNA was kept at $-80^{\circ} \mathrm{C}$ until further analysis. Sequencing libraries were prepared using the INCPM mRNA Seq protocol. Sixty base pair single reads were sequenced on 1 lanes of an Illumina HiSeq.

For transcriptome analysis, the raw-reads were subjected to a filtering and cleaning procedure. The SortMeRNA tool was used to filter out rRNA. ${ }^{16}$ Next, the FASTX Toolkit (http://hannonlab.cshl.edu/fastx_toolkit/ index.html, version 0.0.13.2) was used to trim read-end nucleotides with quality scores $<30$, using the FASTQ Quality Trimmer, and to remove reads with less than $70 \%$ base pairs with a quality score $\leq 30$ using the FASTQ Quality Filter.

Clean reads were aligned to the human genome extracted from National Center for Biotechnology Information (NCBI) (GRCh38; https://www..ncbi.nlm .nih.gov/genome/guide/human/) using Tophat2 software (v2.1). ${ }^{17}$ Gene abundance estimation was performed using Cufflinks (v2.2) ${ }^{18}$ combined with gene annotations from the NCBI. Heatmap visualization was performed using R Bioconductor. ${ }^{19}$ Differential expression analysis was completed using the edge $\mathrm{R} R$ package. ${ }^{20}$ Genes that varied from the control more than twofold, with an adjusted $p$-value of no more than 0.05 , were considered differentially expressed. ${ }^{21}$ Venn diagrams were generated using the online tool at 
bioinformatics.psb.ugent.be/webtools/Venn/. Functional annotation of the significant expressed genes was extended using PANTHER (www.pantherdb.org/), based on gene ontology (GO) categories assigned to the human. The KEAGG database (www.genome.jp/kegg/) was used for pathways analysis using the KEAGG mapper tool (www.genome.jp/kegg/tool/map_pathway2.html).

\section{Statistical analyses}

Results are presented as mean \pm SE of replicate analyses and are either representative of or include at least two independent experiments. Mean of replicates was subjected to statistical analyses by Tukey-Kramer test $(p \leq 0.05)$ using the JMP statistical package and considered significant when $p \leq 0.05$. Different letters above bars indicate statistically significant differences between mean by one-way analysis of variance (ANOVA). For dose-response assays, data points were connected by nonlinear regression lines of the sigmoidal dose-response relation. GraphPad Prism was employed to produce dose-response curve and IC50 doses. FlowJo software was used to analyze FACS data.

\section{Results}

C. sativa extracts from fresh inflorescences are active in reducing cell viability in colon cancer cell lines Cytotoxic activity was determined as the level of cell viability in HCT 116 cells for absolute ethanol extracts of fresh $(\mathrm{C} 2 \mathrm{~F})$ and heated $(\mathrm{C} 2 \mathrm{~B})$ inflorescences of $C$. sativa (CS12 var.) following overnight treatment. Treatments with $\mathrm{C} 2 \mathrm{~F}$ or $\mathrm{C} 2 \mathrm{~B}$ were found to significantly reduce HCT 116 cancer cell viability with a similar level of activity (Fig. 1A, B). Moreover, although both ethanol extracts of C. sativa, $\mathrm{C} 2 \mathrm{~F}$ and $\mathrm{C} 2 \mathrm{~B}$, have similar cytotoxic activity on colon cancer cells HCT 116 (Fig. 1A, B), the activity of $\mathrm{C} 2 \mathrm{~F}$ on $\mathrm{CCD}-18 \mathrm{Co}$ healthy colon cells was reduced. C2F had IC50 of 83.9 and $144.2 \mu \mathrm{g} / \mathrm{mL}$ on HCT 116 and CCD-18Co cell lines, respectively (Fig. 1A, C). On the other hand, C2B was more active on CCD-18Co than on HCT 116 cell lines, with IC50 of 54.63 and $84.1 \mu \mathrm{g} / \mathrm{mL}$, respectively (Fig. $1 \mathrm{~B}, \mathrm{D}$ ).

We previously determined the chemical composition of $C$. sativa extracts from fresh and heated inflorescences. $\mathrm{CBD}, \mathrm{CBG}$, and $\mathrm{THC}$ were found in $\mathrm{C} 2 \mathrm{~B}$, whereas in $\mathrm{C} 2 \mathrm{~F}$ the acidic forms of all the above compounds (i.e., CBDA, CBGA, THCA) were mostly present. ${ }^{22}$

\section{C2F and F7 have cytotoxic activity on human} colon polyp biopsies

Adenomatous polyps are the primary premalignant precursors of CRC. Hence, to examine a possibility for a therapeutic or preventive potential of the extracts, we studied biopsies of adenomatous polyps and healthy tissue from patients scheduled for colonoscopy. Biopsy tissues of polyps and normal colon tissue of the same patient were exposed to C2F and F7 for $16 \mathrm{~h}$ followed by cell separation and Resazurin assay to determine tissue cell viability. Both $\mathrm{C} 2 \mathrm{~F}$ and F7 treatments significantly reduced cell viability of both polyp and healthy tissues (Table 1).

\section{F7 interaction with other $C$. sativa cannabis fractions induces cytotoxic activity}

$\mathrm{C} 2 \mathrm{~F}$ is as active as $\mathrm{C} 2 \mathrm{~B}$ on cancer cells, but is less active on normal cell lines; therefore, C2F was further analyzed for cytotoxic activity. Previously, we showed that the HPLC fraction 7 of C2F F7 (that contains mainly THCA) has only moderate cytotoxic activity against HCT 116. However, the combination of F7 with the other $\mathrm{C} 2 \mathrm{~F}$ fractions led to a marked increase in cytotoxic activity. ${ }^{22}$ In this case, the interaction between $\mathrm{F} 7$ and the other $C$. sativa $\mathrm{C} 2 \mathrm{~F}$ fractions was further examined for each fraction separately.

Forty-eight hour treatment with F7 led to only a moderate effect on cell viability, whereas combinations of F7 with F2 or F3 was found to have increased cytotoxic activity (Fig. 2A). Only combination of F7 and F3 (in concentrations found in $\mathrm{C} 2 \mathrm{~F}$ ) resulted with increased cytotoxic activity despite the low (F3) to moderate (F7) activity of each (Fig. 2B). Both F7 and F7+ F3 treatments were cytotoxic to HT-29 and Caco-2 cell lines (Supplementary Fig. S1). As expected, F7+F2 or F7 + F3 were much less potent on the normal CCD-18Co cell line (Supplementary Fig. S2).

\section{Synergistic interaction of $C$. sativa fractions \\ F7 + F3 and F3 chemical composition}

To determine whether the interaction of F7 and F3 is synergistic, that is, their combined activity is greater than the sum of their separate activities, the extent of activity in different combined concentrations of F7 and F3 was examined. The IC50 of F7 and F3 was determined to be 21.7 and $35.47 \mu \mathrm{g} / \mathrm{mL}$, respectively (Supplementary Fig. S3). Subsequently, the partial effect of the drugs was calculated according to the Bliss Independence Model for each combination experiment. Four to six concentrations of each combination were examined. Synergistic interactions were found for the following combinations: F7 at its IC50 $(21.7 \mu \mathrm{g} / \mathrm{mL})+$ F3 at concentrations of $26.7,20.0$, and $13.3 \mu \mathrm{g} / \mathrm{mL}$; and $\mathrm{F} 3$ at its IC50 $(35.5 \mu \mathrm{g} / \mathrm{mL})+\mathrm{F} 7$ at concentrations of 15.8 , 

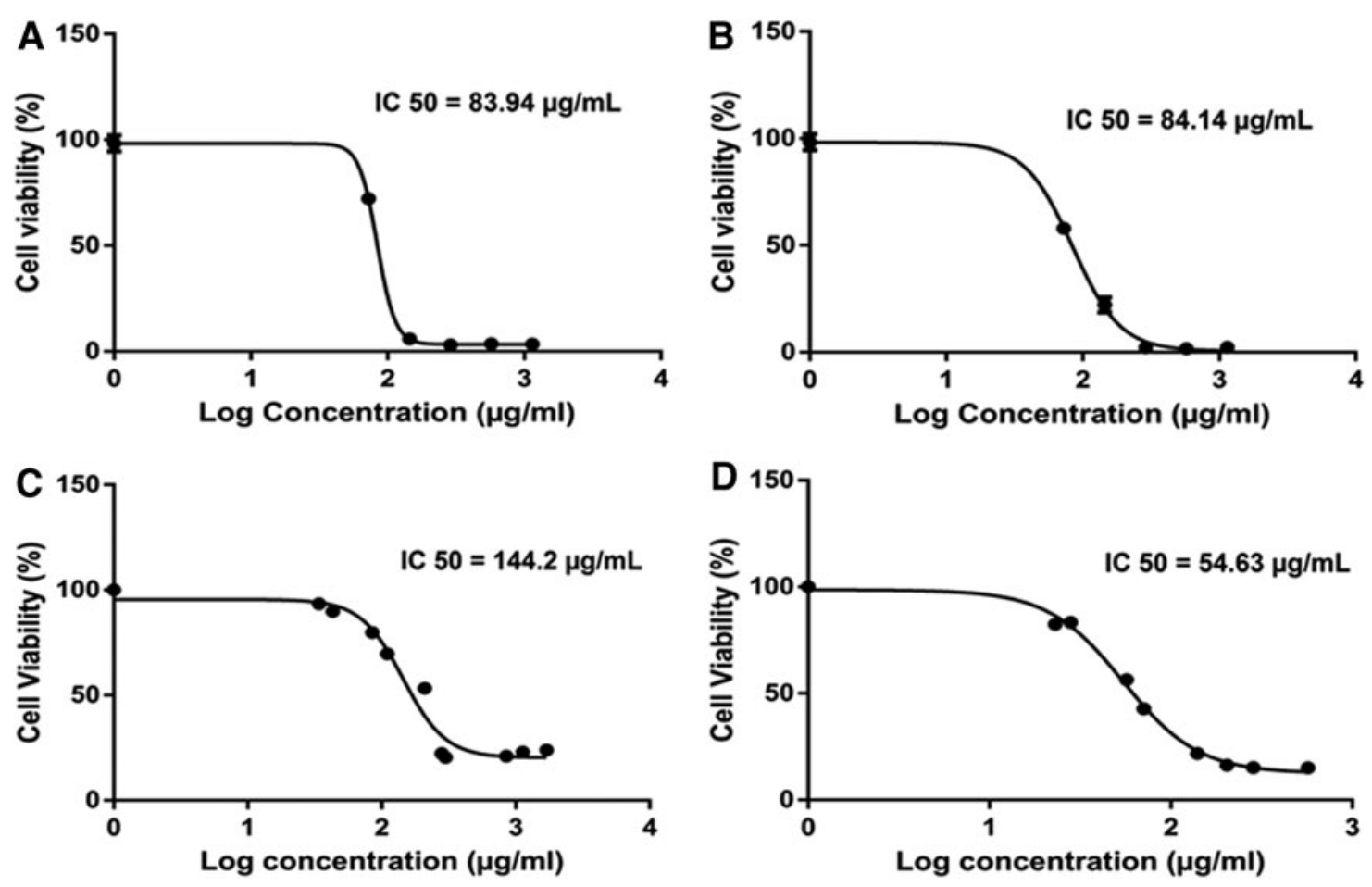

FIG. 1. Dose-effect curves of Cannabis sativa ethanol extracts on the viability of HCT 116 colon cancer and CCD-18Co colon healthy cells. Dose-effect curves of $C$. sativa ethanol extracts of fresh inflorescences (C2F) (A; IC50 = 83.9 $\pm 0.9 \mu \mathrm{g} / \mathrm{mL}, 95 \%$ confidence interval = 83.2-84.7), heated inflorescences (C2B) (B; IC50=84.1 $\pm 1.3 \mu \mathrm{g} /$ $\mathrm{mL}, 95 \%$ confidence interval $=83.1-85.2)$ on the viability of HCT 116 colon cancer cells, and C2F $(\mathbf{C} ; \mathrm{IC} 50=144.2 \pm$ $1.1 \mu \mathrm{g} / \mathrm{mL}, 95 \%$ confidence interval = 142.9-145.5), C2B (D; IC50 =54.63 $\pm 2.03 \mu \mathrm{g} / \mathrm{mL}, 95 \%$ confidence interval $=53.09-56.17$ ) on the viability of CCD-18Co colon healthy cells. Cell viability determined by alamarBlue fluorescence (Resazurin assay). HCT 116 and CCD-18Co cells were seeded (10,000 per well) in triplicate in $100 \mu \mathrm{L}$ of growing media and incubated for $24 \mathrm{~h}$ at $37^{\circ} \mathrm{C}$ in a humidified $5 \% \mathrm{CO}_{2}-95 \%$ air atmosphere. Cells were treated with C2F, C2B at different dilutions along with $50 \mathrm{ng} / \mathrm{mL}$ TNF- $\alpha$ for $16 \mathrm{~h}$. The cells were next incubated with alamarBlue for $4 \mathrm{~h}$. Relative fluorescence at the excitation/emission of $544 / 590 \mathrm{~nm}$ was measured. Values were calculated as the percentage of live cells relative to the nontreated control (cells without TNF- $\alpha$ and treatments) after reducing the autofluorescence of alamarBlue without cells $(n=3)$. For dose-response assays, data points were connected by nonlinear regression lines of the sigmoidal dose-response relation. GraphPad Prism was used to produce doseresponse curve and IC50 doses for C2F and C2B. TNF, tumor necrosis factor.

Table 1. Cannabis sativa C2F and F7 Cytotoxic Activity on Human Colon Polyp and Healthy Colon Tissue

\begin{tabular}{llcc}
\hline Sample & \multicolumn{1}{c}{ Treatment } & \% Living cells & Statistics \\
\hline Healthy & $\mathrm{NT}+\mathrm{MeOH}$ & 100 & $\mathrm{~A}$ \\
& $\mathrm{C} 2 \mathrm{~F}(1.25 \mathrm{mg} / \mathrm{mL})$ & 18.41 & $\mathrm{~B}$ \\
& $\mathrm{~F} 7(0.4 \mathrm{mg} / \mathrm{mL})$ & 18.43 & $\mathrm{~B}$ \\
Polyp & $\mathrm{NT}+\mathrm{MeOH}$ & 100 & $\mathrm{a}$ \\
& $\mathrm{C} 2 \mathrm{~F}(1.25 \mathrm{mg} / \mathrm{mL})$ & 7.81 & $\mathrm{~b}$ \\
& $\mathrm{~F} 7(0.4 \mathrm{mg} / \mathrm{mL})$ & 13.30 & $\mathrm{~b}$ \\
\hline
\end{tabular}

Cytotoxic activity was calculated as \% of living cells from control of tissue treated with methanol only $(\mathrm{NT}+\mathrm{MeOH})$. Healthy biopsy of normal tissue, $n=3$; polyp biopsy of adenomatous polyp, $n=3$.

NT, nontreated.
11.9 , and $7.9 \mu \mathrm{g} / \mathrm{mL}$ (Table 2). Since the Bliss Independence Model has high risks on false-positive results, ${ }^{23}$ we have confirmed synergy between F7 and F3 by the CI method (Supplementary Table S1).

Furthermore, the combination of F3 at its IC50 with F7 resulted in approximately a threefold reduction in F3 IC50 (from 35.5 to $10.8 \mu \mathrm{g} / \mathrm{mL}$ ). The combination of F7 at its IC50 with F3 resulted in an 11-fold reduction in F7 IC50 (from 21.7 to $1.9 \mu \mathrm{g} / \mathrm{mL}$ ).

F3 was found to contain mainly CBGA (at $91.20 \%$ ), CBN (3.67\%), CBCA (3.53\%), terpenes and terpene- 

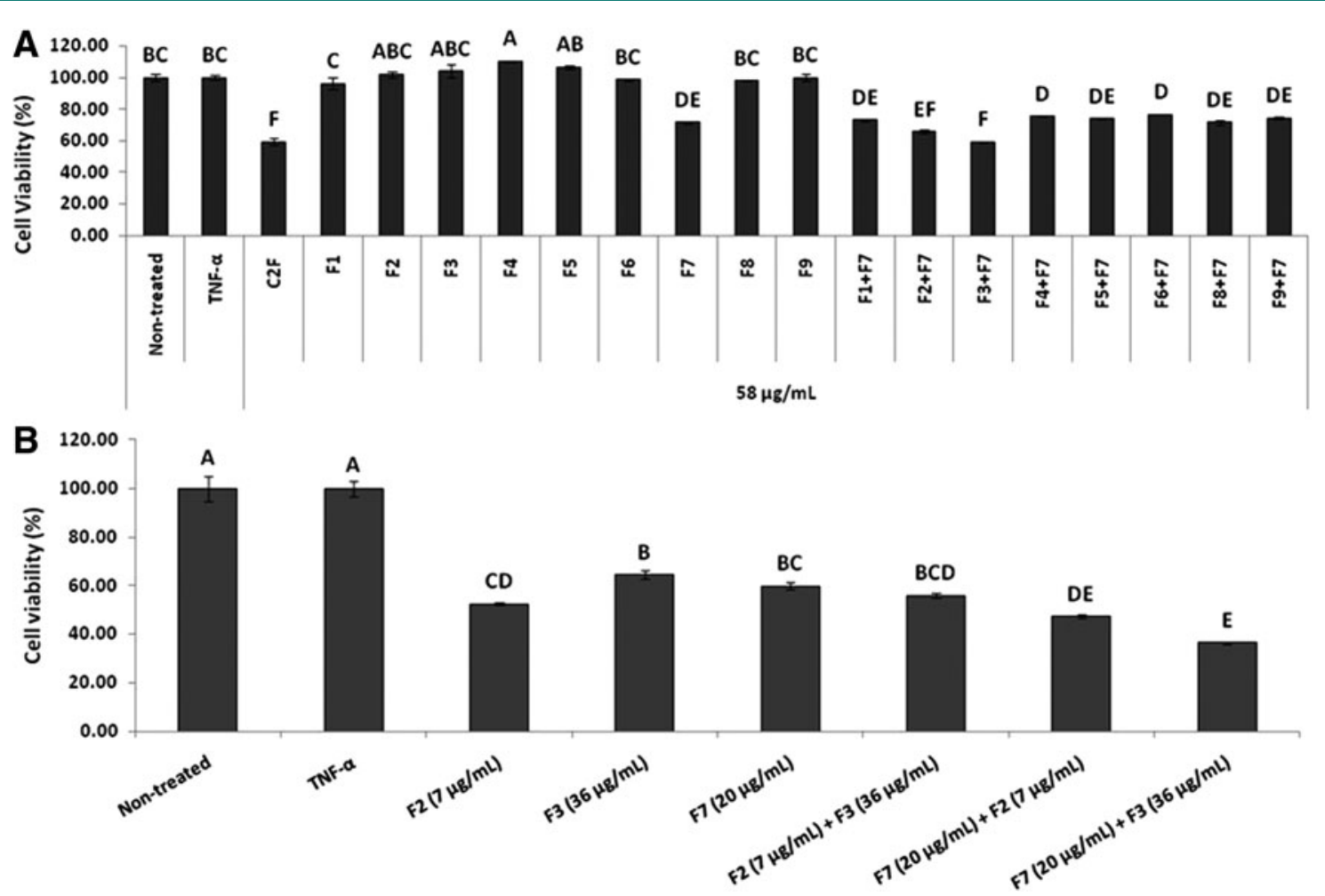

FIG. 2. Effect of Cannabis sativa C2F and HPLC fractions (F1-F9) in different combinations on HCT 116 cell viability. (A) Determination of HCT 116 cell viability using XTT assay as a function of live cell number. Cells were seeded and treated with $C$. sativa ethanol extracts (C2F) F1-F9, excluding F7 (HPLC fractions of C2F) and F1-F9, including F7 (HPLC fractions of C2F) at the IC50 dose of $\mathrm{C} 2 \mathrm{~F}$ crude $(58 \mu \mathrm{g} / \mathrm{mL})$, and F1-F9 diluted as C2F crude along with $50 \mathrm{ng} / \mathrm{mL}$ of TNF- $\alpha$ for $48 \mathrm{~h}$. The cells were then incubated with XTT reagent for $2 \mathrm{~h}$. Absorbance was recorded at $490 \mathrm{~nm}$ with $650 \mathrm{~nm}$ of reference wavelength. Values were calculated as the percentage of live cells relative to the nontreated (cells without TNF- $\alpha$ and treatments) control after reducing the absorbance without cells. (B) Determination of synergism of C2F Fraction 7 (F7) in combination with Fraction 2 (F2) and Fraction 3 (F3) on HCT 116 cell viability using XTT assay as a function of live cell number. Cells were seeded and treated with IC50 doses of F2 $(7 \mu \mathrm{g} / \mathrm{mL}), F 3(36 \mu \mathrm{g} / \mathrm{mL}), F 7(20 \mu \mathrm{g} / \mathrm{mL})$, the combinations of F2 +F3, F7 + F2, and F7 + F3, along with $50 \mathrm{ng} / \mathrm{mL}$ of TNF- $\alpha$ for $48 \mathrm{~h}$. Subsequently, the cells were incubated with XTT reagent for $2 \mathrm{~h}$. Absorbance was recorded at $490 \mathrm{~nm}$ with $650 \mathrm{~nm}$ of reference wavelength. Values were calculated as the percentage of live cells relative to the nontreated control (cells without TNF- $\alpha$ and treatments) after reducing the absorbance without cells. Error bars indicate $\pm S E(n=3)$. Levels with different letters are significantly different from all combinations of pairs by Tukey-Kramer HSD. HPLC, high-performance liquid chromatography; HSD, honest significant difference.

ethanol compounds $(0.72 \%)$, diterpenes $(0.33 \%)$, and short free fatty acids $(0.37 \%)$. The rest $(0.18 \%)$ of compounds present in F3 are unidentified. Combined treatments with the purified compounds that constitute most of the fractions, that is, THCA in F7 and CBGA in F3, also resulted in synergistic interactions (Table 3). We have confirmed synergy between THCA and CBGA by the CI method (Supplementary Table S2).
Treatment of HCT 116 cells with C. sativa F7 and F7 + F3 induced apoptotic cell death

Cell sorting for cell viability by FACS based on Alexa Fluor $^{\circledR}$ 488/Annexin V staining suggested that treatment for $48 \mathrm{~h}$ with F7 leads to a large proportion of cells that are in early or late apoptosis in comparison to controls (nontreated and TNF- $\alpha$ or Methanol $[\mathrm{MeOH}]$-treated cells); for example, $8.5 \pm 0.4$ or 
Table 2. Synergism Calculation for Combinations of Fractions (F7 and F3)

\begin{tabular}{|c|c|c|c|c|c|c|}
\hline & \multicolumn{6}{|c|}{ A. F7 $(20 \mu \mathrm{g} / \mathrm{mL})$} \\
\hline & F3 $(40.0 \mu \mathrm{g} / \mathrm{mL})$ & F3 $(26.7 \mu \mathrm{g} / \mathrm{mL})$ & F3 $(20 \mu \mathrm{g} / \mathrm{mL})$ & F3 $(13.3 \mu \mathrm{g} / \mathrm{mL})$ & F3 $(10 \mu \mathrm{g} / \mathrm{mL})$ & F3 $(6.7 \mu \mathrm{g} / \mathrm{mL})$ \\
\hline Calculated value & 22.64 & 50.42 & 52.13 & 52.45 & 52.52 & 54.49 \\
\hline \multirow[t]{3}{*}{ Experimental value } & 32.21 & 38.94 & 43.31 & 51.86 & 59.61 & 69.24 \\
\hline & \multicolumn{6}{|c|}{ B. F3 $(36 \mu \mathrm{g} / \mathrm{mL})$} \\
\hline & \multicolumn{2}{|c|}{ F7 $(23.8 \mu \mathrm{g} / \mathrm{mL})$} & $F 7(15.8 \mu \mathrm{g} / \mathrm{mL})$ & \multicolumn{2}{|c|}{$F 7(11.9 \mu \mathrm{g} / \mathrm{mL})$} & $F 7(7.9 \mu \mathrm{g} / \mathrm{mL})$ \\
\hline Calculated value & \multicolumn{2}{|c|}{29.95} & 49.84 & \multicolumn{2}{|c|}{58.67} & 58.06 \\
\hline Experimental value & \multicolumn{2}{|c|}{32.16} & 33.96 & \multicolumn{2}{|c|}{38.85} & 41.97 \\
\hline
\end{tabular}

(A) F7 in constant concentration of $20 \mu \mathrm{g} / \mathrm{mL}$ and F3 in different concentrations (6.7-40 $\mu \mathrm{g} / \mathrm{mL}$ ). Italicized values are concentrations, which showed synergism between fractions, as was determined by XTT assay on HCT 116 cells. (B) F3 in constant concentration of $36 \mu \mathrm{g} / \mathrm{mL}$ and F7 in different concentrations $(7.9-23.8 \mu \mathrm{g} / \mathrm{mL})$. Italicized values are concentrations, which showed synergism between fractions, as was determined by XTT assay on HCT 116 cells. The partial effect of the drugs was calculated according to the Bliss Independence Model for each combination experiment.

$30.1 \pm 4.1$ for nontreated (NT) or F7 for late apoptosis, respectively. This proportion was even significantly higher in F7+F3-treated cells at $48 \mathrm{~h}(42.5 \pm 2.1$ for late apoptosis), but treatment with F3 only did not lead to cell death (Fig. 3 and Supplementary Fig. S4). At $24 \mathrm{~h}$, apoptosis was not yet evident, but a slight and significant reduction of cell necrosis was found with the F7+F3 treatment $(4.0 \pm 0.2$ or $6.7 \pm 0.3$ for F7 + F3 or NT, respectively; Fig. 3 and Supplementary Fig. S4). These results suggest that F7 or F7 + F3 treatments may act through induction of apoptosis.

\section{Treatment of HCT 116 cell line with C. sativa F7}

or F7+F3 leads to S or G0/G1 cell cycle arrest, respectively

Cell sorting for cell cycle analysis by FACS based on PI staining suggested that treatment of the cells with $\mathrm{F} 7+\mathrm{F} 3$ led at $24 \mathrm{~h}$ to a marked increase in proportion of cells in G0/G1 phase in comparison to controls (NT and treated with TNF- $\alpha$ or $\mathrm{MeOH}$; $43.2 \pm 0.0$ or $73.2 \pm 1.7$ for NT or F7+F3, respectively; Fig. 4) Treatment with F7 or F3 (F3 to a lesser extent) led to an increase in cells in S phase in comparison to controls (Fig. 4).

\section{F7 and F7 + F3 have cytotoxic activity on human}

\section{colon polyp biopsies}

We next examined whether treatment with $\mathrm{F} 7+\mathrm{F} 3$ leads to an increase in the cytotoxic activity. We treated biopsy tissues of polyps and normal colon tissue from the same patient with reduced concentrations of F7, F3, or F7 + F3 for $16 \mathrm{~h}$ followed by cell separation and Resazurin assay to determine tissue cell viability. Results varied between patients $(n=4)$. For some, F7 + F3 treatment was more effective than only F7 or F3, whereas for other patients, treatment with F7+F3 did not improve cytotoxicity in comparison to F7 or F3 only (Table 4). In all cases but one (P4), treatments reduced polyp cell viability.

\section{F7 + F3 treatment induces distinct profile of gene expression in HCT 116 cells in comparison to F7 or F3 treatments}

To identify genes differentially expressed in HCT 116 cells following treatment with $C$. sativa extract fractions, we performed RNA sequence analysis of HCT 116 cells $6 \mathrm{~h}$ post-treatment with F7, F3, or F7 + F3. Sample correlation tests of RNA sequencing results suggested that those of the cells treated with F7 or F3 were clustered together, and those of control treatment clustered in a separate clade. However, RNA sequencing results of the treatment with $\mathrm{F} 7+\mathrm{F} 3$ at the concentrations shown above to act synergistically (i.e., $20 \mathrm{mg} / \mathrm{mL}$ for F7 and $36 \mu \mathrm{g} / \mathrm{mL}$ for F3) were clustered as an outgroup clade to the rest of the treatments (Fig. 5A).

In the experiments, 2283 genes were found to be differentially expressed in cells treated with F7 +F3, but not in cells treated with F7 or F3 only, compared with the control (Fig. 5B). Among the differentially expressed genes specific to the F7+F3 treatment to be discussed in this study are those involved with cell cycle G1/S phase transition, Wnt signaling pathway (Fig. 6), and p53 and apoptosis signaling pathways (Fig. 7). Gene expression data of those genes are listed in Supplementary Table S3.

\section{Discussion}

The present study provides evidence of a synergistic interaction of cytotoxic activity against colon cancer cells between two $C$. sativa extract fractions. F7 contains mainly $\mathrm{THCA}^{22}$ whereas F3 contains mainly CBGA 

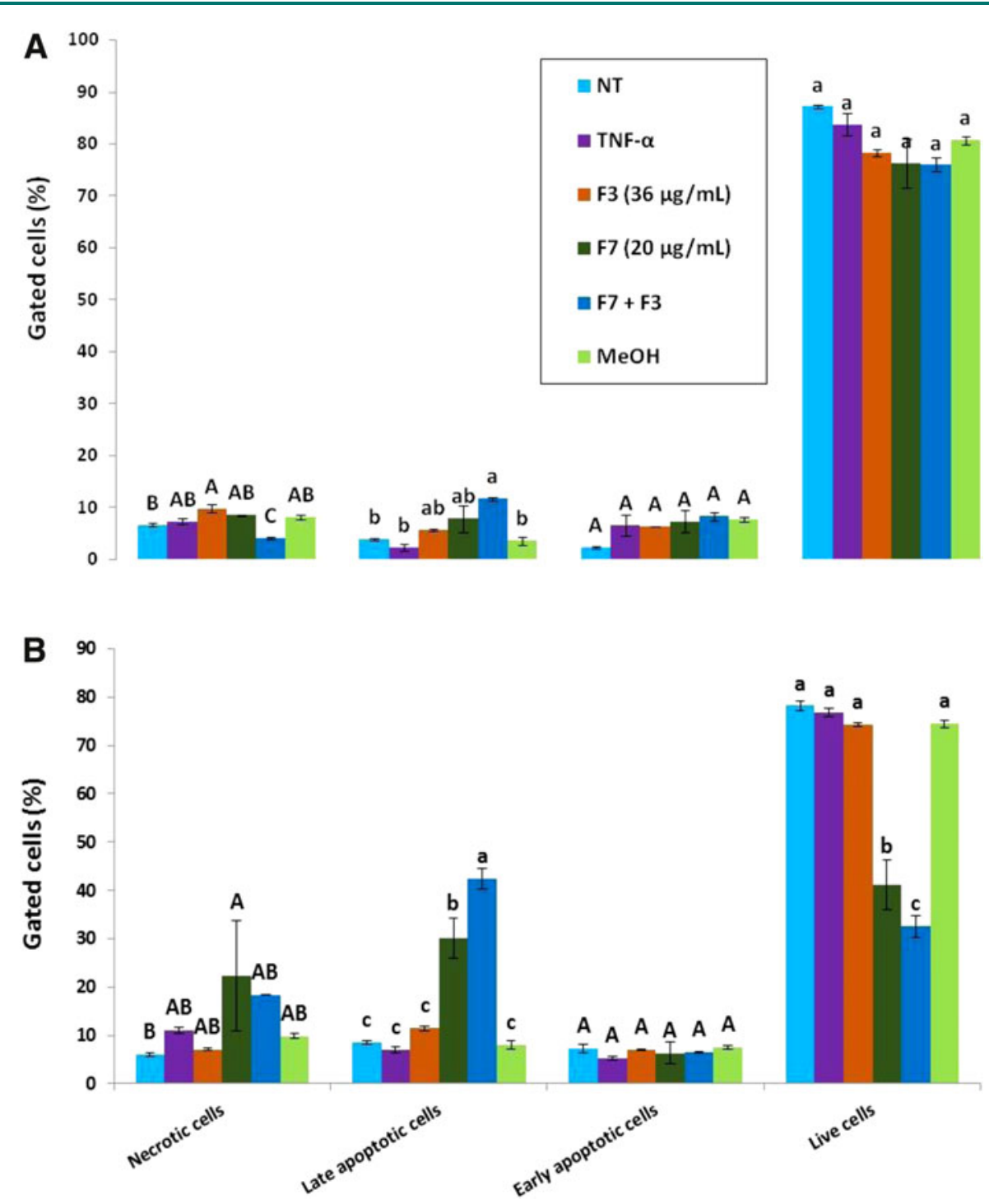

FIG. 3. Determination of apoptosis or necrosis as cytotoxic effect of F7, F3, or F7+F3 on HCT 116 cells. HCT 116 cells were treated with F7 $(20 \mu \mathrm{g} / \mathrm{mL}), \mathrm{F} 3(36 \mu \mathrm{g} / \mathrm{mL})$, the combination of F7 with F3 and solvent control (methanol) along with TNF- $\alpha(50 \mathrm{ng} / \mathrm{mL})$ for $24 \mathrm{~h}$ (A) or $48 \mathrm{~h}$ (B). The treated cells were harvested and analyzed in FACS following Annexin V-FITC and PI staining. Shown are the percentages of live, necrotic, early, and late apoptosis cells, analyzed from 10,000 events per treatment. FACS, fluorescence-activated cell sorting; PI, propidium iodide.

but with additional minute amounts of other cannabinoids and terpenes. Several cell-based experiments have demonstrated that THCA has immunomodulatory, anti-inflammatory, neuroprotective, and antineoplastic activity. ${ }^{24} \mathrm{CBGA}$ was shown to have cytotoxic activity with IC50 of $\sim 40 \mu \mathrm{M}$, and essentially no synergic activity with $\mathrm{CBD}$ on acute lymphocytic leukemia. $^{25}$
However, synergism between plant-produced compounds was previously suggested because, in some cases, unrefined content of the flower extract, with its different extracted compounds, may have an advantage over the activity of an isolated compound. ${ }^{12,13}$ Activity of the purified compounds comprising most of the fractions, that is, THCA in F7 and CBGA in F3, was synergistic as well. Nevertheless, in vivo experiment for validation 
Table 3. Synergism Calculation for Combinations of Standards (THCA and CBGA)

\begin{tabular}{|c|c|c|c|c|c|c|c|c|}
\hline & \multicolumn{8}{|c|}{ A. THCA $(13.1 \mu \mathrm{g} / \mathrm{mL})$} \\
\hline & $\begin{array}{c}\text { CBGA } \\
(53.3 \mu \mathrm{g} / \mathrm{mL})\end{array}$ & $\begin{array}{c}C B G A \\
(40.0 \mu \mathrm{g} / \mathrm{mL})\end{array}$ & \multicolumn{2}{|c|}{$\begin{array}{c}C B G A \\
(28.0 \mu \mathrm{g} / \mathrm{mL})\end{array}$} & \multicolumn{2}{|c|}{$\begin{array}{c}C B G A \\
(20.0 \mu g / m L)\end{array}$} & $\begin{array}{c}C B G A \\
(13.3 \mu \mathrm{g} / \mathrm{mL})\end{array}$ & $\begin{array}{c}C B G A \\
(6.7 \mu g / m L)\end{array}$ \\
\hline Calculated value & 15.10 & 17.69 & \multicolumn{2}{|c|}{22.97} & \multicolumn{2}{|c|}{50.19} & 44.37 & 52.49 \\
\hline \multirow[t]{3}{*}{ Experimental value } & 15.69 & 15.15 & & & & & 19.29 & 19.44 \\
\hline & \multicolumn{8}{|c|}{ B. CBGA $(28.0 \mu \mathrm{g} / \mathrm{mL})$} \\
\hline & $\begin{array}{c}\text { THCA } \\
(50.0 \mu \mathrm{g} / \mathrm{mL})\end{array}$ & $\begin{array}{c}\text { THCA } \\
(30.0 \mu \mathrm{g} / \mathrm{mL})\end{array}$ & $\begin{array}{c}\text { THCA } \\
(25.0 \mu \mathrm{g} / \mathrm{mL})\end{array}$ & & & $\begin{array}{c}\text { THCA } \\
(12.0 \mu \mathrm{g} / \mathrm{mL})\end{array}$ & $\begin{array}{c}\text { THCA } \\
(6.0 \mu \mathrm{g} / \mathrm{mL})\end{array}$ & $\begin{array}{c}T H C A \\
(4.0 \mu g / m L)\end{array}$ \\
\hline Calculated value & 10.53 & 20.43 & 21.25 & & & 47.60 & 70.59 & 69.18 \\
\hline Experimental value & 16.56 & 14.40 & 16.90 & & & 28.69 & 29.68 & 42.44 \\
\hline
\end{tabular}

(A) THCA in constant concentration of $13.1 \mu \mathrm{g} / \mathrm{mL}$ and CBGA in different concentrations (6.7-53.3 $\mu \mathrm{g} / \mathrm{mL})$. Italicized values are concentrations, which showed synergism between standards, as was determined by XTT assay on HCT 116 cells. (B) CBGA in constant concentration of $28 \mu \mathrm{g} / \mathrm{mL}$ and THCA in different concentrations $(4.0-50.0 \mu \mathrm{g} / \mathrm{mL}$ ). Italicized values are concentrations, which showed synergism between standards, as was determined by XTT assay on HCT 116 cells. The partial effect of the drugs was calculated according to the Bliss Independence Model for each combination experiment.

CBGA, cannabigerolic acid; THCA, tetrahydrocannabinolic acid.

of synergism would be necessary. Often only additive effects are observed in vivo. For example, cannabinoid CB1 antagonist and systemic cholecystokinin-1-induced (CCK1) receptor agonist had additive effects on CCK1induced feeding suppression in rats, providing a framework for combined therapies. ${ }^{26}$ Should this be the case for the interactions between the identified fractions and compounds in the present study, that is, additive rather than synergistic interaction in vivo, combined treatment could be a potential improvement over standard of care alone, particularly because of the low toxicity profile of cannabinoids.

The cytotoxic activity of F7 or F7 + F3-involved cell apoptosis supports other studies, which suggest that cannabis-derived compounds induce apoptosis. ${ }^{27,28}$ The evidence that F7 treatment led to $S$ phase cell

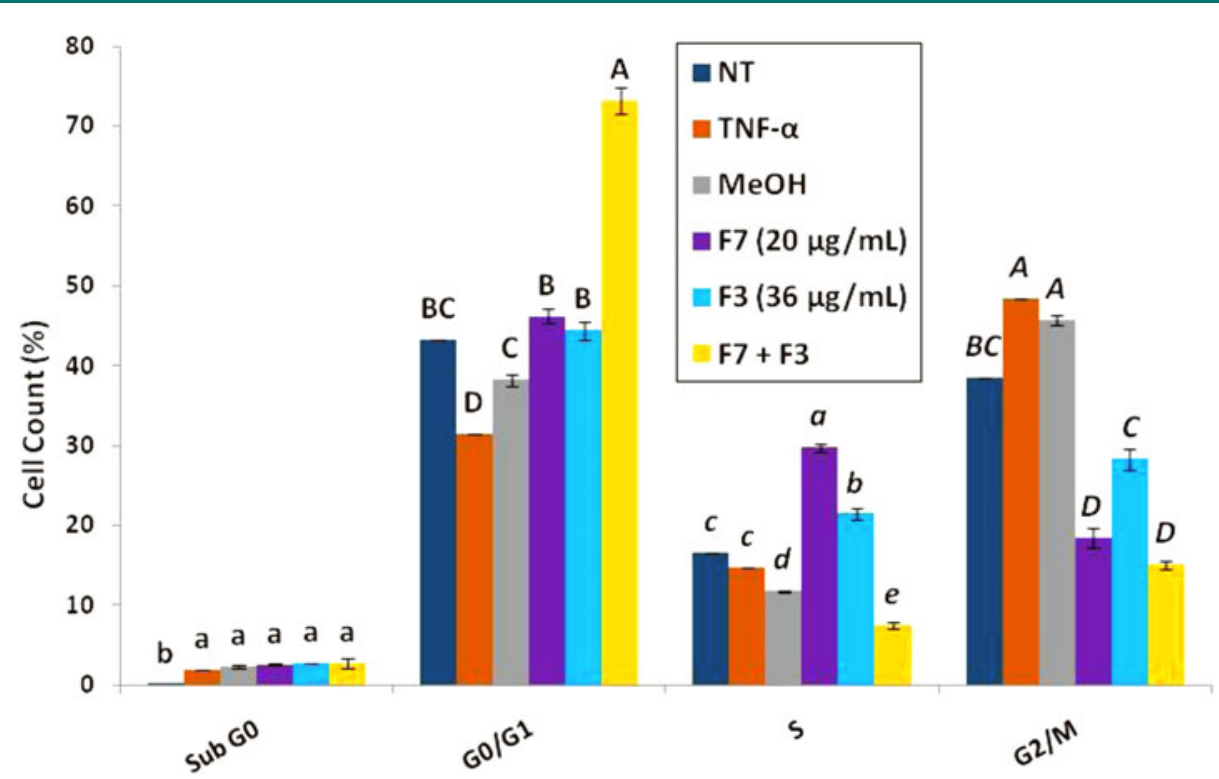

FIG. 4. Determination of stages of cell cycle arrest induced by F7, F3, or F7+F3 in HCT 116 cells. Starved HCT 116 cells were treated with F7 $(20 \mu \mathrm{g} / \mathrm{mL}), \mathrm{F} 3(36 \mu \mathrm{g} / \mathrm{mL})$, the combination of F7 with F3 and solvent control (methanol) along with TNF- $\alpha(50 \mathrm{ng} / \mathrm{mL})$ for $24 \mathrm{~h}$. The treated cells were harvested, fixed, and analyzed in FACS following PI staining. The percentage of cells in Sub-G0, G0/G1, S, and G2/M phase were analyzed from 10,000 events per treatment. 
Table 4. Cannabis sativa F7, F3, and F7 + F3 Cytotoxic Activity on Human Colon Polyp and Healthy Colon Tissue

\begin{tabular}{|c|c|c|c|c|c|}
\hline \multicolumn{6}{|c|}{$\%$ Living cells } \\
\hline Sample & & P1 & P2 & P3 & P4 \\
\hline \multirow[t]{4}{*}{ Healthy tissue } & NT & $100^{\mathrm{A}}$ & $100^{A}$ & $100^{A}$ & $100^{B}$ \\
\hline & F3 & $68.5^{\mathrm{B}}$ & $51.3^{B}$ & $18.1^{\mathrm{B}}$ & $122.5^{A}$ \\
\hline & F7 & $54.4^{C}$ & $25.2^{C}$ & $4.9^{c}$ & $97.3^{C}$ \\
\hline & $\mathrm{F} 3+\mathrm{F} 7$ & $55.4^{\mathrm{BC}}$ & $30.0^{C}$ & $7.6^{c}$ & $16.3^{D}$ \\
\hline \multirow{4}{*}{ Polyp } & NT & $100^{\mathrm{a}}$ & $100^{\mathrm{a}}$ & $100^{\mathrm{a}}$ & $100^{c}$ \\
\hline & F3 & $24.4^{\mathrm{b}}$ & $77.2^{\mathrm{b}}$ & $13.0^{c}$ & $119.7^{\mathrm{b}}$ \\
\hline & F7 & $15.4^{c}$ & $63.4^{b c}$ & $5.8^{\mathrm{d}}$ & $142.1^{\mathrm{a}}$ \\
\hline & $\mathrm{F} 3+\mathrm{F} 7$ & $16.1^{c}$ & $51.7^{c}$ & $33.5^{\mathbf{b}}$ & $40.6^{\mathrm{d}}$ \\
\hline
\end{tabular}

Cytotoxic activity was calculated as \% of living cells from control of tissue treated with methanol only (NT + MeOH). Healthy biopsy of normal tissue $(n=4)$ Polyp biopsy of adenomatous polyp $(n=4)$. Percentages with different letters are significantly different from all combinations of pairs by Tukey HSD.

HSD, honest significant difference.

cycle arrest, whereas F7+F3 treatment led to G0/G1 arrest suggests that the synergistic interaction between F7 + F3 leads to a different form of regulation on cell cycle progression, compared with only F7.

In the F7 + F3 treatment, but not in the F7 treatment, the gene expression involved in G1/S transition was suppressed. The suppressed genes include cyclin E2 (geneID: 9134), by $\sim 10$-fold. Cyclin E2 mRNA levels oscillate throughout the cell cycle and reach highest levels at the G1/S boundary; cyclin E2 is considered rate limiting for G1 progression. ${ }^{29}$ Repression of cyclin E2 in the F7+F3 treatment may account for the G1 arrest. Interestingly, expression of cyclin E1 (geneID: 898) is also repressed by F7 + F3 treatment (by a multiple of $\sim 2.5$ ). Since cyclin $E 1$ and cyclin E2 have some redundancy, suppression of both further explains the F7+F3 effect on G1 arrest. Moreover, overexpression of both cyclin E2 and cyclin E1 positively affects cell proliferation in some cancer cell lines. ${ }^{30}$ Their reduction might again suggest that the F7 + F3 treatment has anticancer properties.

The Wnt family of secreted glycoproteins induces signaling involved in processes of cell proliferation,
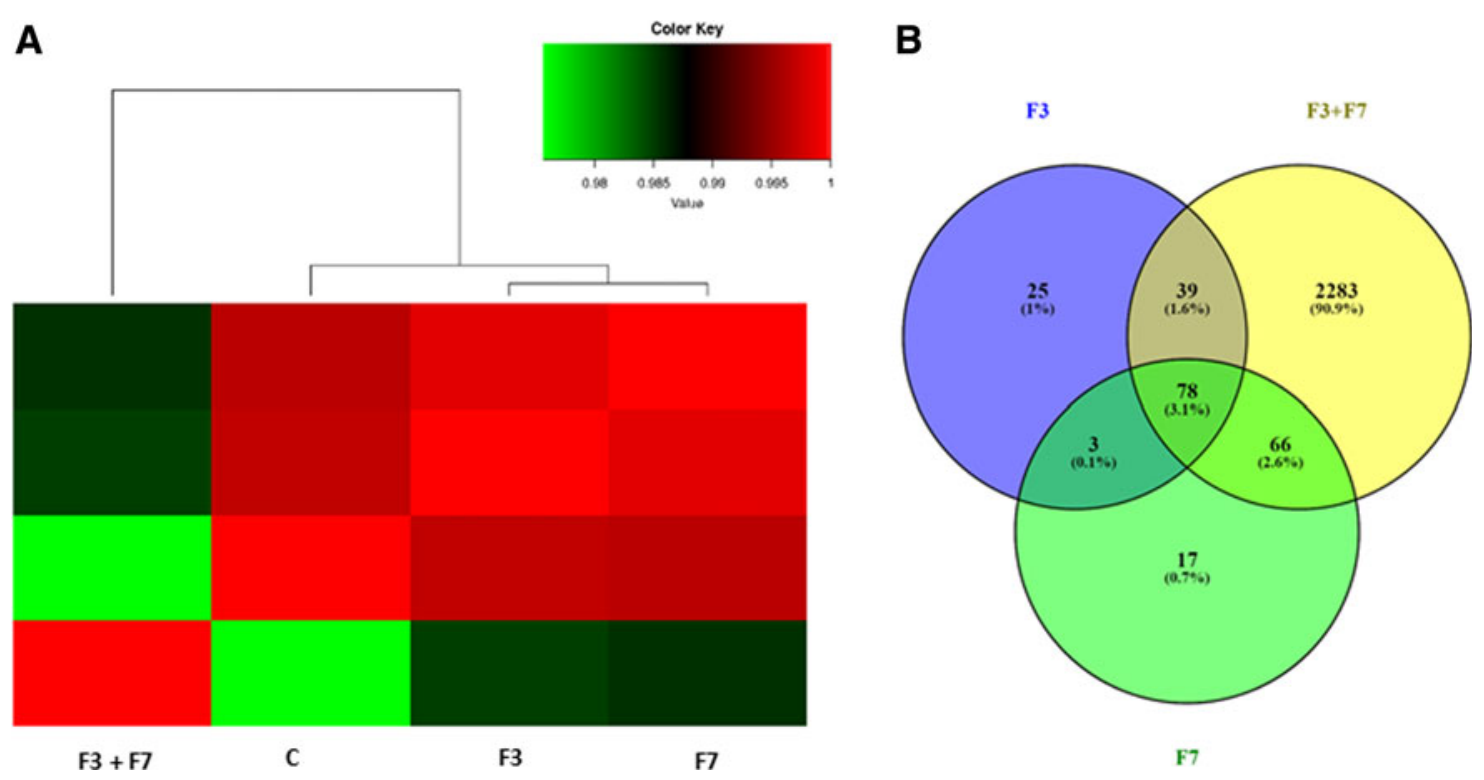

FIG. 5. Hierarchical clustering and Venn diagram of genes significantly differentially expressed in HCT 116 cells treated with F7, F3, or F7 + F3. (A) Hierarchical clustering and Pearson correlations among the four conditions based on the gene expression (counts-per-million) followed by a log2 transform. Pearson correlations were calculated with the R software. (B) Venn diagrams illustrating the relationships between significantly differentially expressed genes in the three treatments against the control. 


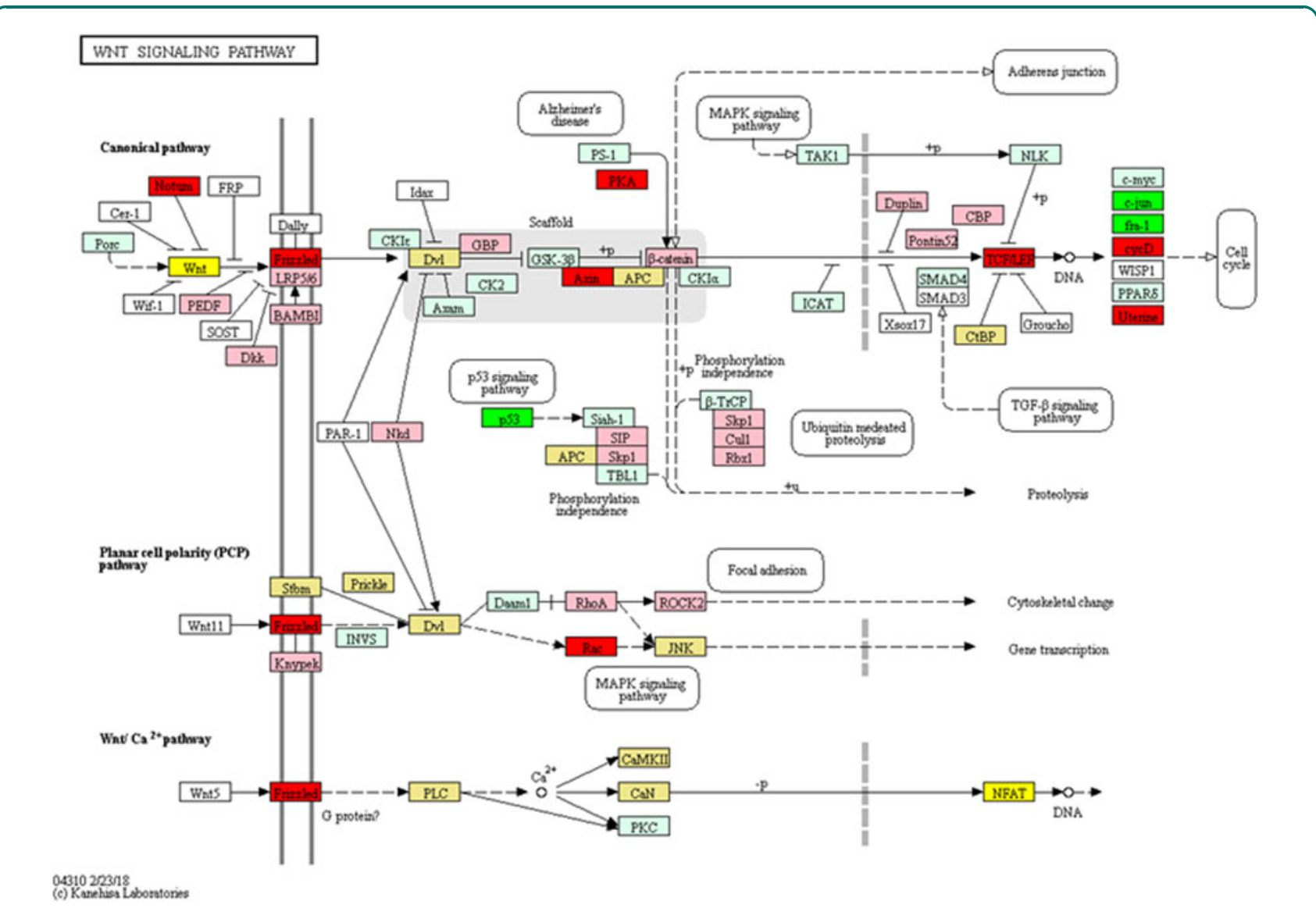

FIG. 6. Genetic pathways of genes differentially expressed in HCT 116 cells treated with F7+F3 versus control for Wnt signaling pathways. Pathways determined according to KEGG (www.genome.jp/kegg/). Green boxessignificantly upregulated genes; red boxes_significantly downregulated genes (edgeR; more than twofold and padj <0.05). Light green boxes-nonsignificant upregulated genes; pink boxes-nonsignificant downregulated genes. Yellow boxes denote genes with multiple gene annotations that encompass both significantly upregulated and downregulated genes; light yellow boxes denote genes with multiple gene annotations that encompass both nonsignificant upregulated and nonsignificant downregulated genes.

differentiation, and oncogenesis, including colon cancer and melanoma; more than $90 \%$ of CRCs involve $\beta$ catenin-dependent WNT signal transduction. ${ }^{31} \mathrm{~F} 7+\mathrm{F} 3$ treatment reduced most differentially expressed genes related to Wnt signaling pathways, including, by a factor of eight, Wnt16 (geneID: 51384) that was previously shown to be involved in leukemia. ${ }^{32}$

Frizzled proteins are one of the major Wnt receptors ${ }^{31}$ and their blockage is one target for anticancer drugs that interfere with canonical Wnt signaling. ${ }^{33}$ The reduction of the expression of Frizzled class receptor 1 (geneID: 8321 ) by $\mathrm{F} 7+\mathrm{F} 3$ treatment may again implicate this treatment with the downregulation of the Wnt pathway. TCF7 expression is also significantly suppressed by the
$\mathrm{F} 7+\mathrm{F} 3$ treatment. Wnt pathway activation leads to $\beta$ catenin accumulation and translocation to the nucleus, where under the control of $\mathrm{T}$ cell factor (TCF), it activates transcription of target genes. ${ }^{31,34}$

TNF- $\alpha$ was suggested to be a prominent effector of colon cancer development. For example, it has been shown that TNF- $\alpha$ treatment in cultured cells resulted in increased chromosomal instability, gene mutations, and amplification ${ }^{35}$ and that TNF- $\alpha$ is a prominent mediator of the initiation and progression of colitisassociated colon carcinogenesis. ${ }^{36}$

Also, elevation in colonic TNF- $\alpha$ leads to protransformational alterations of key components of the Wnt signaling pathway. ${ }^{37}$ Interestingly, in our study 


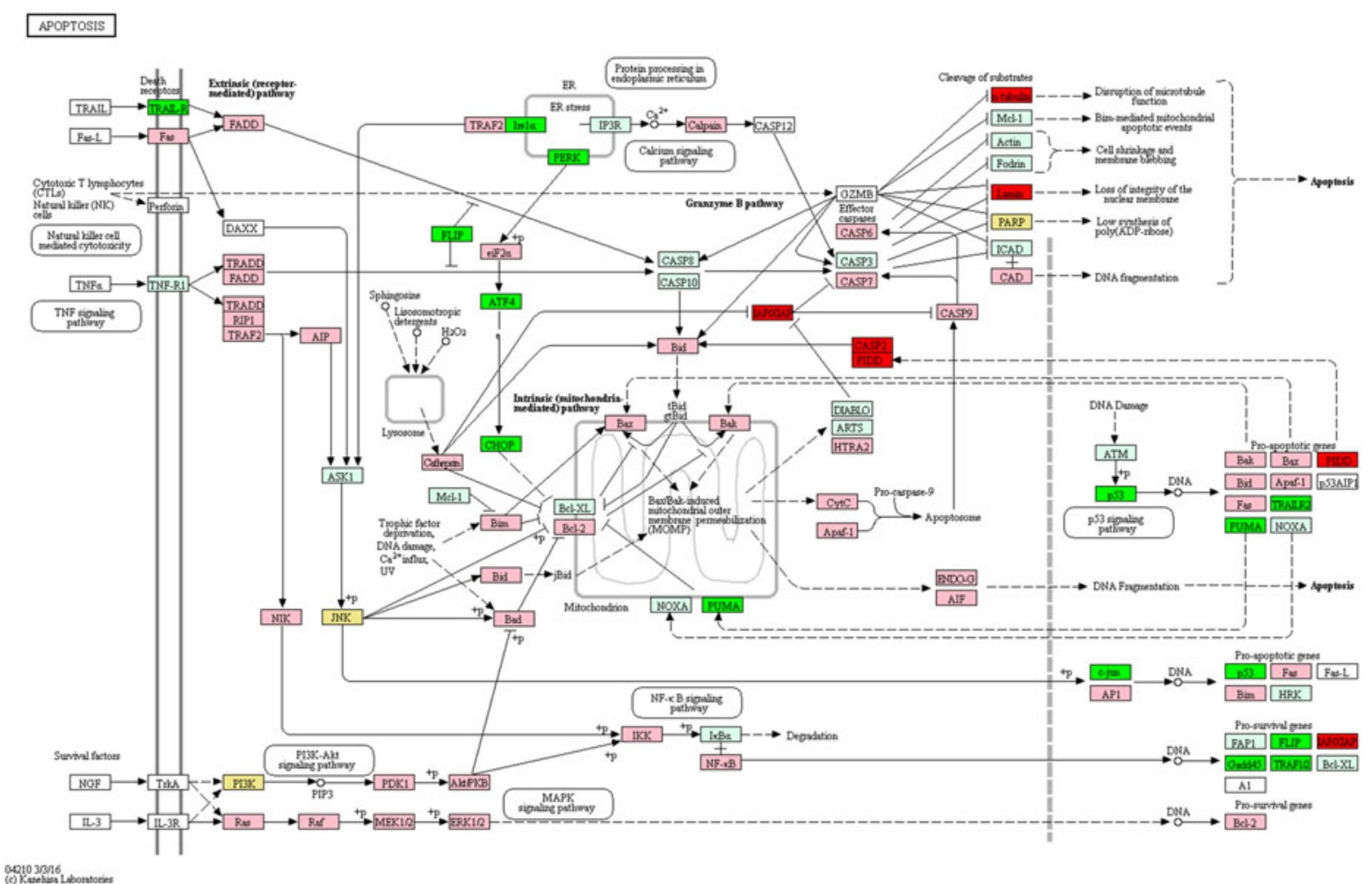

FIG. 7. Genetic pathways of genes differentially expressed in HCT 116 cells treated with F7 + F3 versus control for apoptotic signaling pathways. Pathways determined according to KEGG (www.genome.jp/kegg/). Green boxes_significantly upregulated genes; red boxes_significantly downregulated genes (edgeR; more than twofold and padj <0.05). Light green boxes-nonsignificant upregulated genes; pink boxes-nonsignificant downregulated genes. Yellow boxes denote genes with multiple gene annotations that encompass both significantly upregulated and downregulated genes; light yellow boxes denote genes with multiple gene annotations that encompass both nonsignificant upregulated and nonsignificant downregulated genes.

where cells are also treated with TNF- $\alpha$, treatment with $\mathrm{F} 7+\mathrm{F} 3$ resulted in differential expression of genes related to the Wnt signaling, suggesting that this treatment may counteract TNF- $\alpha$-induced CRC. Further studies are needed to examine this suggestion.

F7+F3 treatment induces several apoptosispromoting genes, including the tumor suppressor $\mathrm{p} 53$ (geneID: 7157) transcription factor that causes cell cycle arrest and apoptosis. P53 signaling is often dysregulated in CRC; patients with the mutant $\mathrm{p} 53$ gene may be resistant to current therapies, leading to a poor prognosis. ${ }^{38}$ TRAIL-R2 (TNFRSF10B; geneID: 8795) expression is also induced by F7 + F3 treatment. It is a receptor for TRAIL to induce apoptosis, but not necroptosis in CRC cells. ${ }^{39}$ However, FLIP (CFLAR; geneID: 8837), which inhibits TRAIL and caspase 8-dependent apoptosis $^{40}$ is upregulated by F7+F3 treatment as well.
PUMA (geneID: 27113, BCL2-binding component 3) BH3-only Bcl-2 family proteins is a p53 downstream target and acts as a mediator for different tumor suppression drugs that treat CRC. ${ }^{41}$ PUMA expression is induced by F7+F3 cell treatment and may indicate the potential to increase PUMA-regulated treatment of CRC by treatment with the combination of F7 + F3 and the relevant drugs. In this case and others, however, additional functional tests in vitro and in vivo are needed to fully confirm and characterize of the pathways activated by $\mathrm{F} 7+\mathrm{F} 3$ cell treatment.

The F7 and F7 + F3 treatments showed only relatively low cytotoxic activity on a normal colon cell line but were active on adenomatous polyps. On the one hand, these extracts do not specifically target colon cancer cells that are a caveat for potential therapy. On the other, since nearly every carcinoma begins with an 
adenoma, ${ }^{42} \mathrm{~F} 3, \mathrm{~F} 7$, and F7 + F3 could be potential candidates for chemopreventive agents to either prevent or suppress progression of neoplastic polyps. The ability of F7 + F3 treatment to induce cell cycle arrest and cancer cell apoptosis further suggests that F7 + F3 treatment may have therapeutic anticancer value.

\section{Acknowledgments}

Research was performed under the authorization of IMCA (Israel Medical Cannabis Agency) for research on medical cannabis. This work was partially financed by The Chief Scientist of the Israel Ministry of Agriculture, grant No. 20-01-0119 that Prof. David Meiri, Technion, Israel, is a collaborator on. Research was partially financed by Meir Medical Center, Kfar Saba, Israel and partially financed by ARO funds no. 2564586-00. MS and DN scholarships are financed partially by Bar Ilan University, Ramat Gan, Israel, and partially by Volcani Center, ARO, Israel. RN and ACV scholarships are financed by ARO Postdoctoral Fellowships Israel - India.

\section{Author Disclosure Statement}

No competing financial interests exist.

\section{References}

1. Siegel RL, Miller KD, Fedewa SA, et al. Colorectal cancer statistics, 2017. CA Cancer J Clin. 2017;67:177-193.

2. Linnekamp JF, Wang X, Medema JP, et al. Colorectal cancer heterogeneity and targeted therapy: a case for molecular disease subtypes. Cancer Res. 2015;75:245-249.

3. Markowitz SD, Bertagnolli MM. Molecular basis of colorectal cancer. N Engl J Med. 2009;361:2449-2460.

4. Baxter NN, Warren JL, Barrett MJ, et al. Association between colonoscopy and colorectal cancer mortality in a US cohort according to site of cancer and colonoscopist specialty. J Clin Oncol. 2012;30:2664-2669.

5. Zauber AG, Winawer SJ, O'Brien MJ, et al. Colonoscopic polypectomy and long-term prevention of colorectal-cancer deaths. N Engl J Med. 2012; 366:687-696.

6. ElSohly MA, Radwan MM, Gul W, et al. Phytochemistry of Cannabis sativa L. Phytocannabinoids. Springer: Berlin, 2017, pp. 1-36.

7. Javid FA, Phillips RM, Afshinjavid S, et al. Cannabinoid pharmacology in cancer research: a new hope for cancer patients? Eur J Pharmacol. 2016; 775:1-14.

8. Greenhough A, Patsos HA, Williams AC, et al. The cannabinoid $\delta 9$-tetrahydrocannabinol inhibits RAS-MAPK and PI3K-AKT survival signalling and induces BAD-mediated apoptosis in colorectal cancer cells. Int J Cancer. 2007;121:2172-2180.

9. Aviello G, Romano B, Borrelli F, et al. Chemopreventive effect of the nonpsychotropic phytocannabinoid cannabidiol on experimental colon cancer. J Mol Med (Berl). 2012;90:925-934

10. Romano B, Borrelli F, Pagano E, et al. Inhibition of colon carcinogenesis by a standardized Cannabis sativa extract with high content of cannabidiol Phytomedicine. 2014;21:631-639.

11. Borrelli $F$, Pagano $E$, Romano $B$, et al. Colon carcinogenesis is inhibited by the TRPM8 antagonist cannabigerol, a Cannabis-derived nonpsychotropic cannabinoid. Carcinogenesis. 2014;35:2787-2797.

12. Ben-Shabat $S$, Fride $E$, Sheskin T, et al. An entourage effect: inactive endogenous fatty acid glycerol esters enhance 2-arachidonoyl-glycerol cannabinoid activity. Eur J Pharmacol. 1998;353:23-31.
13. Russo EB. Taming THC: potential cannabis synergy and phytocannabinoid-terpenoid entourage effects. Br J Pharmacol. 2011;163:1344-1364.

14. Delaney WE, Yang $H$, Miller MD, et al. Combinations of adefovir with nucleoside analogs produce additive antiviral effects against hepatitis $B$ virus in vitro. Antimicrob Agents Chemother. 2004;48:3702-3710.

15. Chou TC, Talalay P. Quantitative analysis of dose-effect relationships: the combined effects of multiple drugs or enzyme inhibitors. Adv Enzyme Regul. 1984;22:27-55.

16. Kopylova E, Noé L, Touzet H. SortMeRNA: fast and accurate filtering of ribosomal RNAs in metatranscriptomic data. Bioinformatics. 2012;28: 3211-3217.

17. Kim D, Pertea G, Trapnell C, et al. TopHat2: accurate alignment of transcriptomes in the presence of insertions, deletions and gene fusions. Genome Biol. 2013;14:R36.

18. Trapnell C, Williams BA, Pertea G, et al. Transcript assembly and quantification by RNA-Seq reveals unannotated transcripts and isoform switching during cell differentiation. Nat Biotechnol. 2010;28:511-515.

19. Gentleman RC, Carey VJ, Bates DM, et al. Bioconductor: open software development for computational biology and bioinformatics. Genome Biol. 2004;5:R80.

20. Robinson MD, McCarthy DJ, Smyth GK. edgeR: a Bioconductor package for differential expression analysis of digital gene expression data. Bioinformatics. 2010;26:139-140.

21. Benjamini $Y$, Hochberg $Y$. Controlling the false discovery rate: a practical and powerful approach to multiple testing. J R Stat Soc B Methodol. 1995: 289-300.

22. Nallathambi R, Mazuz M, lon A, et al. Anti-inflammatory activity in colon models is derived from $\Delta$ 9-tetrahydrocannabinolic acid that interacts with additional compounds in Cannabis extracts. Cannabis Cannabinoid Res. 2017;2:167-182.

23. Zhao W, Sachsenmeier K, Zhang L, et al. A new bliss independence model to analyze drug combination data. J Biomol Screen. 2014;19: 817-821.

24. Moreno-Sanz G. Can you pass the acid test? Critical review and novel therapeutic perspectives of $\Delta 9$-tetrahydrocannabinolic acid A. Cannabis Cannabinoid Res. 2016;1:124-130.

25. Scott KA, Shah S, Dalgleish AG, et al. Enhancing the activity of cannabidiol and other cannabinoids in vitro through modifications to drug combinations and treatment schedules. Anticancer Res. 2013;33:4373-4380.

26. Orio L, Crespo I, Lopez-Moreno JA, et al. Additive effects of cannabinoid CB1 receptors blockade and cholecystokinin on feeding inhibition. Pharmacol Biochem Behav. 2011;98:220-226.

27. Fisher T, Golan H, Schiby $G$, et al. In vitro and in vivo efficacy of nonpsychoactive cannabidiol in neuroblastoma. Curr Oncol. 2016;23:S15-S22.

28. Velasco G, Sánchez C, Guzmán M. Anticancer mechanisms of cannabinoids. Curr Oncol. 2016;23:S23-S32.

29. Payton M, Coats S. Cyclin E2, the cycle continues. Int J Biochem Cell Biol. 2002;34:315-320.

30. Caldon CE, Musgrove EA. Distinct and redundant functions of cyclin E1 and cyclin E2 in development and cancer. Cell Div. 2010;5:2.

31. Niehrs C. The complex world of WNT receptor signalling. Nat Rev Mol Cell Biol. 2012;13:767-779.

32. Mazieres J, You L, He B, et al. Inhibition of Wnt16 in human acute lymphoblastoid leukemia cells containing the $t(1 ; 19)$ translocation induces apoptosis. Oncogene. 2005;24:5396-5400.

33. Gurney A, Axelrod F, Bond CJ, et al. Wnt pathway inhibition via the targeting of Frizzled receptors results in decreased growth and tumorigenicity of human tumors. Proc Natl Acad Sci U S A. 2012;109:11717-11722.

34. Chen W-Y, Liu S-Y, Chang Y-S, et al. MicroRNA-34a regulates WNT/TCF7 signaling and inhibits bone metastasis in Ras-activated prostate cancer. Oncotarget. 2015;6:441-457.

35. Yan B, Wang H, Rabbani ZN, et al. Tumor necrosis factor- $\alpha$ is a potent endogenous mutagen that promotes cellular transformation. Cancer Res. 2006;66:11565-11570.

36. Popivanova BK, Kitamura K, Wu Y, et al. Blocking TNF- $\alpha$ in mice reduces colorectal carcinogenesis associated with chronic colitis. J Clin Invest. 2008;118:560-570.

37. Liu Z, Brooks RS, Ciappio ED, et al. Diet-induced obesity elevates colonic TNF- $\alpha$ in mice and is accompanied by an activation of Wnt signaling: a mechanism for obesity-associated colorectal cancer. J Nutr Biochem. 2012;23:1207-1213. 
38. Li X-L, Zhou J, Chen Z-R, et al. P53 mutations in colorectal cancermolecular pathogenesis and pharmacological reactivation. World J Gastroenterol. 2015;21:84-93.

39. Nahacka Z, Svadlenka J, Peterka M, et al. TRAIL-induces apoptosis but not necroptosis in colorectal and pancreatic cancer cells preferentially via the TRAIL-R2/DR5 receptor. Biochim Biophys Acta. 2017;1865:522-531.

40. Fulda S. Targeting apoptosis for anticancer therapy. Semin Cancer Biol. 2015;31:84-88

41. Wang $H$, Zhang $L$, Yang $X$, et al. PUMA mediates the combinational therapy of 5-FU and NVP-BEZ235 in colon cancer. Oncotarget. 2015;6:14385-14398.

42. Winawer S, Fletcher R, Rex D, et al. Colorectal cancer screening and surveillance: clinical guidelines and rationale-Update based on new evidence. Gastroenterology. 2003;124:544-560.

Cite this article as: Nallathambi $R$, Mazuz $M$, Namdar $D$, Shik $M$ Namintzer D, Vinayaka AC, lon A, Faigenboim A, Nasser A, Laish I, Konikoff FM, Koltai H (2018) Identification of synergistic interaction between cannabis-derived compounds for cytotoxic activity in colorectal cancer cell lines and colon polyps that induces apoptosis-related cell death and distinct gene expression, Cannabis and Cannabinoid Research 3:1, 120-135, DOI: 10.1089/can.2018.0010.

\section{Abbreviations Used}

$A C F=$ aberrant crypt foci

ANOVA $=$ analysis of variance

$\mathrm{CBD}=$ cannabidiol

$\mathrm{CBDA}=$ cannabidiolic acid

$\mathrm{CBG}=$ cannabigerol

$\mathrm{CBGA}=$ cannabigerolic acid

$\mathrm{CBN}=$ cannabinol

$\mathrm{CRC}=$ colorectal cancer

$\mathrm{Cl}=$ combination-index

$\mathrm{FACS}=$ fluorescence-activated cell sorting

$\mathrm{GC} / \mathrm{MS}$ = gas chromatograph/mass spectrometry

$\mathrm{GO}=$ gene ontology

$\mathrm{HPLC}=$ high-performance liquid chromatography

$\mathrm{NCBI}=$ National Center for Biotechnology Information

$\mathrm{NT}=$ nontreated

$\mathrm{PBS}=$ phosphate-buffered saline

$\mathrm{PI}=$ propidium iodide

$\mathrm{THC}=$ tetrahydrocannabinol

THCA $=$ tetrahydrocannabinolic acid

$\mathrm{TNF}=$ tumor necrosis factor

Publish in Cannabis and Cannabinoid Research

Cannabis and

Cannabinoid

Research
- Immediate, unrestricted online access

- Rigorous peer review

- Compliance with open access mandates

- Authors retain copyright

- Highly indexed

- Targeted email marketing

liebertpub.com/can 